\title{
The Role of Business Dictionaries
}

\author{
Valbone Zeqiraj-Nimani \\ valbonazeqiraj@hotmail.com
}

Kolegji Universitare Biznesi, Gjakovë

\begin{abstract}
English language is an international language or one can freely say that it is an everyday language no matter which country you live in or which country you come from. We can say so, considering the fact that business has become one of the life neccesities and knowing that doing bussines means having to do with different people from all over the world, and the language used in every field is English. Nowadays no studies, no travelling, no business can be run without being able to speak English language. In response to these needs, this article is an attempt to provide a guided approach to ESP dictionaries design for business students at tertiary level.. When designing an English course, the primary issue is the analysis of learners' specific needs and the appropriate literature that suits those needs. Learners want to learn EOP (English for Occupational Purpose), EBE (English for Business and Economics), EAP (English for Academic Purposes) etc, all for instrumental reasons. Some learners are preparing for future jobs in which they will use English, whereas others want to learn it to improve their current job performance in dealing with particular partners or customers. All of these purposes can be achieved only by using the proper dictionary which will enable learners to learn their ESP in a faster and easier way. A bilingual dictionary is necessary due to the level of the students at the beginning. An english-english one is only used with advanced learners. It is absolutely necessary to use one, but very often teachers first have to teach learners how to take advantage of it and take time to work with examples on the different meanings depending on the context
\end{abstract}

Keywords; EBE, entry, business, dictionary, translation, Anglicism, comparison, explanation etc.

JEL- Clasification: A; A2

\section{Introduction}

With the globalization of trade and economy and the continuing increase of international communication in various fields, the demand for English for Specific Purposes is expanding, especially in countries where English is taught as a Foreign Language.

ESP ( English for Specific Purposes) has been referred to as " applied ELT ( English language teaching) as the content and the aims of any course are determined by the needs of specific groupof learners( Dudly Evans 1997). ESP is often divided into EAP ( English for Academic Purposes),preparing students to write academic papers, taking lecture notes and studying for their exams, and EOP ( English for Occupational Purposes) teaching general English or particular workplace training and development. EOP is further devided into EBE ( English for Business and Economics), professional english and vacational english ( English for turism, nursing, aviation, and bricklaying). 
In some English speaking countries for instance in Great Britain, Canada, America etc. govermnets are launching initiatives to help economic migrants obtain the practical English skills necessary to function in their working place. For example,new English to Speakers of Other Languages ( ESOL) for Work Qualificationsin the United Kingdom are designed to help employers and employees access courses which offer them the functional language skills demanded across a variety of employment sectors such as customer care, helth and safety.

\section{The Role of EBE Dictionaries}

Learners learn languages when they have opportunities to understand and work with language in a context that they comprehend and find interesting. Before starting to learn a new language every learner should consider the following questions:

- What do learners need to do with English?

- Which of the skills do they need to master and how well?

- Which genres do they need to master either for comprehension or production purposes?

In this wiev, EBE ( English for Business and Economics) is a poweful means for such opportunities . Learners will acquire English as they work with materials which they find interesting and relevant and which they can use in their professional work or further studies. Learners of the business English are generally aware of the purposes for which they will need to use it. Having already oriented their education toward a specific field, they see their English training as complementing their orientation. Knowlege of the subject area enables the students to identify a real context for the vocabulary and structures of the business English classroom.In such way, the learners can take advantages of what they already know about the subject matter to learn English.

As we mentioned above EBE ( English for business and economics) focuses on the language of business that learners need in the workplace. This can take the form of:

Everyday language which is used in social situations

General business language which can be used in a variety of business contexts

Context specific language used by a particular industry or profession.

The precise mix of language taught in English courses depends upon the needs of particular groups of learners.

EBE also focuses on business communication skills, for example, making presentations, taking part in meetings, writing reports. That's why EBE dictionaries tend to give learners the vocabulary and structure to develop these skills and the chance to practise using them. ( www.british council.com)

If you make grammar mistake, it may be "wrong " but very often people will understand you anyway. But, if you do not know the exact word that you need, it is very frastrating for you, and the person you are talking to. Therefore, learning specific vocabullary by using specific dictionaries and specific books is a very important part of learning English.

Learners should think about the kind of vocabulary they need. What about social English? The language of business letters? Building EBE vocabullary is a big job- students can help themselves by choosing the things that are most use to them and learning those first. 
Apart from reading and using the dictionary it is very useful source to use things learners meet everyday at work, look at the letter they receive in their office even if their English is really poor, then open their dictionary and look up for the unknown words, it will help them for sure.

When using a specific dictionary learners should not just learn new words. Good dictionaries tell them how to use them, which words does a word combine with .By combining different words many word partnerships are formed, and a good dictionaries give examples of the way in which words go together.

\section{1. answer a. visitor}

\section{2. wellcome b. a letter}

\section{3. type c. the phone}

All the above words on the left need another word from the right, to form a partnership. So, if we say ;

Type a visitor is completely wrong , because no visitor can be typed, but we can

Type a letter but

\section{Wellcome a visitor}

EBE courses tend to be based on the needs of specific groups of learners. Learners want to learn business English for instrumental reasons. Some are preparing for future jobs in which they will use English, whereas others want to learn it to improve their current job performance in dealing with particular partners or customers.

EBE dictionaries and books in general also focus on preparing learners business communication skills, for example, making presentations, taking part in meetings, writing reports. they tend to give learners the vocabulary and structure to develop these skills and the chance to practise using them. ( lan McKenzie in English for business studies )

\section{Analysing the composition of EBE dictionaries}

Using dictionaries while learning a foreign language is a must, as it helps learners to check the meaning , the pronounciation and the spelling. More over it gives the learner a chance to see the word in examples and also see its synonyms.

Dictionaries are as good as water to be swallowed with the food you are eating to asimilate, so like english language you won't digest it's ssence, word meaning and the word classes unless you have a very helpfull and well planned dictionary.

I usually recommend that students switch to a monolingual dictionary after some time because a bilingual dictionary just doesn't give enough detail or show how to use it in a sentence. Depending on the context the choice of word may differ and a bilingual dictionary just lists possibilties but not necessarily the correct ones Although the vast majority of dictionaries are designed for the learners of the general English the EBE dictionaries are desinged to give these specialized entries based on a totally different field from the once of general English. Not all dictionaries have the same composition, content or organization. Considering the role of the EBE dictionaries learners of languages should try to find the one which suits their field of interest. 


\section{The dictionaries compared :}

- A trilingual dictionary -English-Italian-Albanian Encyclopedic Dictionary written by llir Hoti about Banking, Business and Economics which provides terms about exchange, accounting, marketing, money, insurance etc

- The Economic Dictionary written by Maksim Konini \& Ilia Peci, a trilingual Dictionary . At the end there is given their equivalent form from

- Oxford Advanced Learner's Dictionary, English-English explanation where everything is better explained and better understood.

\subsubsection{Entry- Administration}

\section{Ed1-}

Dege e drejtimit te nje subjekti dhe te cdo organizate ne pergjithesi.Administrimi konsiston ne njohjen operative, ne njohuri te formave te organizimit te subjekteve te biznesit dhe te organizatave te te gjitha llojeve.

Further on the author gives the explanation of all kinds of administration such as:

Administration Costs - expenses - kosto te administrimit.Teresia e shpenzimeve

administrative brenda nje subjekti te biznesit ne nje periudh te caktuar kohore.

Administration department -Departamenti administrative. Departamenti I nje subjekti biznesi , organizate apo institucioni qe bene administrimin dhe merret me problemin e tij apo saj .

Administration order- urdher likuidimi-Urdher I leshuar ne rast falimentimi te biznesit nga ana e gjykates apo nga ndonje subject I barasvlefshem.

Administrative accounting- kontabilitet administrativPjese e procesit kontabel qw ka te beje me drejtimin.

Administrative action- veprim administrative - veprim I cili kryhet si rezultat I permbushjes se nje vendimi te organit drejtues dhe administrues te nje subjekti te biznesit.Ky veprim perfshin gjithe fushen e administrimit .

Administrative audit- revision, rishikim, kontrollim administrative .Proces I verifikimit te saktesise, ligjeshmerise dhe rregulleshmerise se operacioneve te propozuara si dhe atyre ne prage per tu ekzekutuar-Auditing.

Administrative Budget-Bugjeti I shpenzimeve administrative .Ndryshe quhet edhe plani financiar I nje firme.

Administrative revenues- te hyra administrative-te hyrat apo te ardhurat qe entet qeveritare te nje vendi realizojne nga sherbimet qe administrata e tyre I ofron publikut.

Administrative review-Rishikim, kontrollim administrative.1. Term I njejte me Administrative control .2.Kontroll kontabel I veprimtarise se nje subjekti biznesi I njejte me Administrative audit.

Administrative Tribunal-Gjykate e specializuar per zgjedhjen e konflikyeve gjyqesore te natyres administrative qe prekin mardheniet e individit me shtetin , me punesimin dhe per te frejtat qe I takojne por qe per arsye te ndryshme nuk I njihen 
ED2.

Administrate-Administration

Administrat publike - public administration- organ I cili ne kuaderin e ndarjes se pushtetit nuk ushtron pushtet legjislativ apo gjyqesor, por qe ne veprimtarin e tij ndikohet nga keto dy pushtete.Strukture ekzekutive ne sherbim te politikes ekonomike dhe sociale.

-ndertese e administrates-Administrative building

-shpenzime administrative -administrative costs( expanses)

-keshill administrative- administrative board

-nenpunes administrativ- employee in the administration

-organ administrativ- administrative body.

-personel I administrates-administrative staff

-administrat locale-local authority

-administrate publike- public servise/administration

-e drejt administrative-administrative law

-urdher administrative-administrative order

ED3.

Administration/noun/1. the activities that are done in order to plan , organize and run a business, school or other institution. Administration costs are passed on to the costumer.

2. the process or act of organizing the way that something is done ; the administration of justice; 3 .The people who plan , organize and run e plan a business, institution etc;university administration

4.the government of a country, especially the USA;This happenden frequently during the Nixon Administration 5./formal/ the act of givin a drug to somebody; the administration of antibiotics.

Administrator-/noun./ A person whose job is to manage and organize public or business affairs of a company or institution ; a hospital administratior.

2.a person who is good on organizing things. She is a brilliant organizer and administrator.

2.1.2 ED1: Entry - Assets-Zoterime, active Bashkesia e mjeteve monetare e financiare, lendore ose jo lendorete shprehura ne njesi monetare.Zoterimet disponohen nga nje subject biznesi ose individ. 
-Asset liability Committee- komiteti I zoterimeve dhe detyrimeve.

-Asset liquidity-likuiditeti I zoterimeve

-AssetLedger-liber I madh kontabel per llogarite active , liber I madh kontabel per llogarite e zoterimeve.

-Asset management Account-llogari e amvisimit te zoterimeve

ED2.

Assets-zoterim,mjet ne pronesi,aktivi I bilancit

ED3

Assets/ noun usually pl./a thing of value, especially of property, that a person or company owns, which can be used or sold to pay debts; the net asset value of the company ; her assets include shares in the company and a house in France.

2.1.3. ED1: Bearer Cheque- Cek I mbajtesit, cek I pruresit. Cek I pagueshem ne te pare dhe I transferueshem pa xhirate. Xhirimi I kryhet ne momentin kur arketohet ne nje sportel bankar.

-Bearer Mortgage Note-vlerenote ipotekare.Instrument detyrimi(debt instrument)qe pala detyruesee leshon ndaj pales kreditore ndaj nje huamarrjeje hipotekare.Intrumenti eshte I transferueshem, sa qe kushdo qe mban titullin konsiderohet pale kreditore.

-Bearer Passbook-libreze ndaj mbajtesit.D o te thot banka e njeh si pronar te depozites personin qe mban kete libreze.

-Bearer Share-aksion ndaj mbajtesit.Aksioni ndaj mbajtesit eshte I transferueshem tek te tjeret, thjesht duke ia levruar qertifikaten, pa kryer regjistrim ne librin e aksionareve apo te ortakeve.

\section{ED2}

-cek/cheque/ Titull krediti , nisur nje banke nga ana e nje personi qe ka mjete te disponueshme ne te I cili permban urdherin e pakushtezuar per te paguar" me te pare" nje shume te caktuar parash ne favor te vete apo nje te treti.

1 cek I bllokuar/stopped/blloked cheque

2 -cek I pambuluar/flash cheque

3 -cek I xhiruar/endorsed cheque

4 I leshoj dikujt nje cek / to make out a cheque to s.o.

5 Cek I bardh-blank cheque/check

6 Cek udhetari-travellers cheque/check. 


\section{ED3}

Cheque_(Br. Eng.)(Am.Eng. check)- a printed form that you can write on and sign as a way of paying for sth. instead of using money; a cheque for $\$ 50$; to write a cheque ; to make q cheque; to pay by cheque.

\section{- blank cheque}

\section{- traveller's cheque}

2.1.4. ED1: Debit-debitim-. Veprim kontabeli kundert me kreditimin. Ne nje llogaridebitimi evidentohet ne anen e majte te shikuar te llogarise.Per llogarit active , gjithenje pasqyron shtim te gjendjes se saj , ndersa per llogarite passive pasqyron pakesim.

-Debit balance-teprice debitore1. teprica debitore e nje llogarie active . ne kontabilitetin e bilancit te nje firme tregon gjendjen e mjeteve qe zoteron firma. 2.ne gjuhen bankare nenkupton tepricen e borxhit qe I ka bankes nje klient ne pozitat e huamaresit. 3 .ne bilancin e nje firme huadhenes eshte teprica e detyrimit qe secili huamarres ka ndaj saj.

debit card-karte debiti-kartepagesa( payment card)electronike dhe jo electronike, zoteruesi I se ciles urdheron qe te debitohet llogaria e tij per nje pagese ne favor te nje perfituesi.

\section{ED2}

Debil debit/side/- shume te hollash qe I detyrohemi dikujt . ana e majte e librit te llogarise ne te cilen regjistrohen shumat qe duhet ti paguhen dikujt.

-debitoj/ to enter on debit side, to debit

-debi dhe kredi/ assets and liabilities, credits and debits

-debitor/ debtor/ personi I cili duhet te paguaj nje shume te caktuar

-debitore/ accounts receivable/ Kontabilitet.Cilesim I pergjitheshem per individ , ndermarrje apo institucione qe detyrohen te paguajne nje shume te caktuar. Bilance Bankar. Kredite e dhena klienteve te ndryshem.

ED3.

Debit-/noun/1.a written note in a bank account or other financial record of a sum of money owed or spent; on the debit side of an account .2.a sum of money taken from a bank account.

2.Debit/verb/ when a bank debits an account, it takes moneyfrom it; the money will be debited from your account each month.

Debtor/noun/ a person, a country or an organization that ows money.

\subsubsection{ED1:}

Entry - Economic and Financial Committee - komiteti Ekonomic dhe Financiar.Organizem I krijuar ne stadin e trete te Bashkimit Ekonomik dhe Monetar( Economic and Monetary Union)Shtetet anetare te Bashkimit Evropian , Komisioni 
Evropian ( europian Commission) dhe Banka Qendrore Evropiane ( Europian Central Bank) caktojne secila nga jo me shume se dy anetarete cilet formojne Komitetin Ekonomik dhe Financiar.

-Economic Aggregates- Agregatet ekonomike- Tregues te pergjitheshem makroekonomik te krijuar nepermjet abstraksionit dhe agregacionit ( aggregation) Agregatet me te rendesishem jane:*agregati I kerkeses( demand aggregation), ${ }^{*}$ agregati I ofertes ( aggregates supply), ${ }^{*}$ agregati I konsumit ( consumption function), ${ }^{*}$ agregati I kursimit (savings aggregate).

9 Econimic Cooperation Administration-administrim per bashkepunim ekonomik- Ent I themeluar ne vitin 1948per administrimin e rreth 6 milion USD te vequara nga qeveria amerikane per ndihmat e vendeve te ndryshme. Ne vitin 1951 u zevendesua nga agjensia e sigurise se ndersjelle(mutual security agency)

\section{ED2-}

Ekonomi/ economy! 1.teresi marredheniesh ne prodhim qe I pergjigjen nje shkalle te caktuar te zhvillimit te forcave prodhuese ne nje rend shoqeror.2. Gjendje materiale dhe financiare e nje vendi, nje zone, nje dege te veprimtarise prodhuese apo e nje familjeje.

-program i zhvillimit ekonomik/ economic development programme/

-ekonomi boterore/ world economy/ Marredheniet dhe bashkepunimi qe krijohet midis ekonomike te vendeve te ndryshme ne kuadrin e trgetisenderkombetare dhe te levizjes se punes dhe kapitalit ndermjet tyre.

system ekonomik nderkombetar/ international economic system/

-komisioni ekonomik boteror/ world economic Commission/

-ekonomi sociale e tregut/social/market economy- model ekonomik I konceptuar nga A.Myler Armak dhe L. Erhard, sipas te cileve krahas funksionimit dhe garantimit nga shteti te konkurences ekonomike, plotesohet kuadri I detyrave ekonomike dhe politike te shtetit me theks objektivat sociale politike.I

ED3.

Economy/ 1.the relationship between production, trade and the supply of money in a particular country or region; the word economy; a market economy ( = one in which the price is fixed according to both cost and demand)

Economics- the study of how a society organizes its money, trade and industry the way in which money influences or is organized within an area of business or society- The economics of the project are very encouraging Economics proffesion - persona profesioni I te cileve eshte ekonomika. Ketu perfshihen profesoret e universiteteve, te qendrave studimore ekonomike, gazetar te profesionit ekonomik, etj te natyres se njejte. Economist- economist- ekspert, specialist I fushes se ekonomise teorike apo te aplikuar.

\subsubsection{ED1.}

Entry - Financial resources- resurse financiare.Pergjat nje kursi normal operacionesh biznesi , eshte bashkesia e zoterimeve te nje firme qe shendrohet ne te holla. 
-financial Statement-raportim financiar1.raport kontabel ku permblidhet ecuria financiare e nje subjekti biznesi pergjate nje periudhe te dhene kohore.perbehet nga keto komponente;"bilanci(balance sheet), ku evidentohet gjendja e te nje firme ne dy momente te ndryshme .* evidenca e te ardhurave ( income statement) .Quhet edhe evidence e operimit te firmes (operating statement) ose evidence per fitime dhe humbje ( profit and loss statement). Evidenton te ardhurat nga shitjet,shpenzimetdhe rezultatin fitim/humbjeqe nje firm ka realizuar pergjate nje periudhe te dhene kohore.

-Finished Goods Inventory -inventare te produkteve te perfunduara ,inventare te produkteve te gateshme.Gjendje mallrash te perfunduara dhe te gatshme per shitje, qe nje firme ka ne nje moment te dhene.Perfshin mallerat ne dyqane dhe ne pika shitje qe jane ne pritje per tu shitur-Inventories.

\section{ED2}

-Finance/Finance/ 1.fushe e veprimtarise ekonomike qe perfshin mjetet monetare dhe veprimet qe kryhen ne to. 2. Dege e administrates shteterore qe merret me keto mjete dhe veprime.

-buxhet financiar/ financial budget

-financa ;purchasing powe of moneyl

-furnitori,furnizuesi/ supplier, contractor,deliverer,dealer. publike/public finances

-kontabilitet financiar/financial accounting, generalaccounts( accountings)

-mjete financiare/funds, capital, finacial facilities.

Fond aksionesh/ investment company( trust)

Fondi Monetar Nderkombetar/International Monetary Fund.

Fondi I sigurimit te depozitave/ Deposit guarantee fund.

ED3.

Finance- noun/ money use to run a business, an activity or a project; finance for education comes from taxpayers,2. the activity of managing money, especially by a government or commercial organization; the Minister of Finance;the finance director, 3.finance- money available to a person, an organization or country ; the way this money is managed; the government/ public/personal finances

Finance/ verb/ to provide money for a project, SYN. Fund. The building project will be financed by government and by public donators .

Filing/noun/ 1 the act of putting documents, letters etc, into a file.

2.something that is placed in an official record; a bankruptcy filing;

2.2. There are some entries not found in every dictionary causing learners difficulties on finding the right translation such as. 
2.2.1. Hammering the Market-goditje tregu,rendim tregu.Shitje intensive nga ana e subjekteve te nje tregu apo burse,kur shitesit mendojne se qmimi real I te sigurtave, mallerave, valutave, dhe vlerave qe disponojne, do te bjere-selling short.

This entry can be found only in the ED1 not in the other two dictionaries.

or

2.2.2. Hard Currancy- money that is easy to exchange for money from another money, because it is not likely to lose its value; the hotel insisted that we pay in hard currency.

Found only in ED3

2.2.3. Offshore banking./ Emertim per operacione bankare nderkombetare, te cilat zhvillohen jashte sistemit monetar te vendit, ku ato realizohen.Operacionet bankare offshore realizohen para se gjithash ne vendet financiare evropiane si Londra dhe Luksenburgu,si dhe ne Azine Juglindore ( tregu Aziatik I dollarit) dhe ne Ameriken e Veriut.

2.2.4. Lease/noun/ an alegal agreement that allows you to use a building, a piece of equipment or some land for a period of time, usually in return for rent; to take out a lease on a flat

2. verb- sth to sb. to use or let sb use sth, especially property or equipment, in exchange for rent, or a regular payment; they lease a land from a local farmer.

2.2.5.- Lizing* - has no Albanian equivalence found- a borrowing is used instead

ED1: Leasing - Thuhet se nje transferim fondi permbushet kur banka e perfituesit ( beneficiary) pranon pagesen ne favor te tij, duke ia kryer pagesen dhe shkarkuar detyrimin qe derguesi kishte ndaj perfituesit. Ky rregull eshte I pacenueshem. Rrezik paraqet vetem kur banka ndermjetese e kryerjes se transferimit te fondit falimenton.

2.2.6.- Zakah Fund- Fondi I ndihmes se vullnetshme- Ne sistemin financiar islamik i referohet nje fondi qe krijohet per te ndihmuar familjet ose individet me te ardhura te pakta, te varfer, te papune, etj. Krijohet nga te ardhurat e cdo subject biznesi a individ ne nje mjedis te ekonomise islamike.

2.2.7.- Zollvereign - Bashkim doganor [ gjermanisht].Term qe se pari haset ne shekullin e XIX, duke iu referuar levizjes per heqjen e pengesave doganore dhe nxitjen e unitetit ekonomik te Gjermanise.

\section{Conclusion}

Using English-English dictionaries is learning the language from professional English teachers in plain english. They can learn what plain English is like as well as what the words they are looking up mean.

I encourage the use of dictionaries and teach learners how to use them by explaining the different abbreviations that are used and with work on the phonetic symbols and 'stress' indications. However, "just as a carpenter needs a hammer, dictionary is the best tool for the job that learners are trying to do."

Learners should be dictionary-oriented!Whatever they do in classes somehow is related to a dictionary. the meaning of a word or correct pronunciation of a word or anything like that should be checked by learners in classes. Also learners should write examples to show how a special word is used in real context, to put it in a nutshell, a dictionary can be the best teacher for English learners if they know the right way of using it. 
Impossibility of having a proper dictionary offering adequate word in Albanian causes the use of anglicisms which make the process of speaking and understanding the language more difficult. For eg. If we talk about Bonds or Assets to an old man, a child or even an adult who does not understand English, it is really difficult to understand the role or even the difference between the two of them . I think that linguistst of both Albanian and English languge should work hard and come up with a dictionary which will be a great help to the learners of EBE or ESP dictionaries.A bilingual dictionary is necessary due to the level of the students at the beginning. An english-english one is only used with advanced learners. It is absolutely necessary to use one, very often teachers first have to teach learners how to take advantage of it ( dictionary) and take time to work with examples on the different meanings depending on the context.

The use of dictionaries is optional in the classrooms, but those who use it get the privilege of learning new words faster because the process of looking the word up in the book will make it permanent in our brains. e-dictionaries are the new trend that have to be applied in every institute, they are really useful.

\section{Bibliography}

[1] Cambridge University Press- lan Mc Kenzie - English for Business Studies

[2] John Flower - Build your Business Vocabulary

[3] www.British council.com

[4] Ilir Hoti- Fjalor encilkopedik

[5] Anglisht-Italisht-Shqip per Banken,Biznesin,Ekonomine- trilingual

[6] English-Italian-Albanian Encyclopedic Dictionary of Economics,Banking and Business-trilingual- January 2001

[7] Maksim Konini- Fjalor Ekonomik

[8] Shqip-Anglisht-Gjermanisht-1997

[9] A.S.Hornby- Oxford Advanced Learner's Dictionary

[10] Oxford University Press.2000

[11] www.esp-world.info 